\title{
Corynespora cassiicola IN SOYBEAN SEEDS - INCIDENCE AND TRANSMISSION
}

\section{Corynespora cassiicola EM SEMENTES DE SOJA: INCIDENCIA E TRANSMISSÃO}

\author{
Augusto César Pereira GOULART ${ }^{\mathbf{1}}$; Carlos Mitinori UTIAMADA ${ }^{\mathbf{2}}$ \\ 1. Pesquisador M.Sc. Embrapa Agropecuária Oeste, Dourados, MS, Brasil. augusto.goulart@embrapa.br; 2. PesquisadorTAGRO - \\ Tecnologia Agropecuária Ltda, Londrina, PR, Brasil
}

\begin{abstract}
The fungus Corynespora cassiicola, the causal agent of the target spot in soybeans, has been considered, from the seed pathology point of view, a seed-borne pathogen of limited importance. Therefore, little importance has been given to the role of the seeds in the transmission of this pathogen. The objectives of this study were to determine the incidence of $C$. cassiicola in soybean seeds and evaluate the effects of this seed-borne pathogen, inoculated in the seeds, concerning to physiological and epidemiological parameters. The experiments were carried out at TAGRO and Embrapa Western Agriculture under lab (blotter test and seed germination test) and greenhouse conditions (growing on test). The fungus C. cassiicola was detected in $11.3 \%$ of the 639 seed samples analyzed, with an average incidence of $0.91 \%$ and a maximum of $8.5 \%$. The transmission of $C$. cassiicola from the seeds to above-ground parts of soybean seedlings was demonstrated, by pathogen establishment on the cotyledon, showing circular lesions with concentric rings, reddish-brown in the center and surrounded by a yellowish-green halo, as a typical symptom of target spot. Reddish-brown lesions on the roots and stem of the seedlings were also observed. Considering a sample seed with $66.0 \%$ of $C$. cassiicola incidence, the symptomatic transmission based on cotyledon symptoms was $42.2 \%$, corresponding to a transmission rate of $2.4: 1$. This is the first report, in a quantified way, about the transmission of $C$. cassiicola from the seeds to above-ground parts of soybean seedlings. When compared to non-inoculated seeds, seed germination, seedling emergence, and seedling initial development were influenced by the presence of the pathogen in the seeds, with the lowest values being observed when the seeds were inoculated.
\end{abstract}

KEYWORDS: Seed pathology. Target spot.

\section{INTRODUCTION}

Target spot of soybean (Glycine max (L.) Merr.) caused by Corynespora cassiicola (Berk. \& Curt.), was first detected in Brazilian soybean fields in 1976, in São Paulo State (ALMEIDA et al.; 1976). Ten years later, the disease was reported in the States of Mato Grosso, Mato Grosso do Sul and Rio Grande do Sul (YORINORI, 1989). According to Godoy (2015), the incidence of this disease has increased in the last crop seasons due to the lower sensitivity/resistance of the fungus to the fungicides most commonly used in soybean crops and/or the introduction of more susceptible host genotypes. Yield losses of 18 to $32 \%$ have been reported on susceptible cultivars (GODOY et al.; 2015). This pathogen spread mainly by wind and spattering of rain (ALMEIDA et al.; 2005) and information about the transmission and spread through soybean seeds was not found.

The fungus $C$. cassiicola has been considered, from the seed pathology point of view, a seed-borne pathogen of limited importance. Therefore, little importance has been given to the role of the seeds in the transmission of this pathogen.

The incidence of this pathogen in the seeds is unusual. However, it can be detected at low levels. In this context, Roim et al. (1999) detected the presence of $C$. cassiicola in soybean seeds, with an average incidence ranging from $0.2 \%$ to $1.3 \%$. Seeds naturally infected, hardly will show high levels of C. cassiicola. However, results obtained by Camargo et al. (2013), showed an average incidence of this pathogen in the seeds ranging from $18.0 \%$ to $43.0 \%$. According to these authors, this can be attributed to the occurrence of favorable environmental conditions for the target spot, particularly rainfall at harvest. This is an uncommon result, being an exception to the rule.

Only a few references were found about the possibility of pathogen spread through infected seeds (SINCLAIR; BACKMAN, 1989; GODOY et al. 2015). There is no guarantee that seed-associated pathogens will infect seedlings, so the simple incidence of pathogens in seeds does not implicate their transmissibility. No scientific studies related to the transmission of $C$. cassiicola by soybean seeds 
Corynespora cassiicola...

were found. Consequently, from the epidemiological point of view, the role of soybean seeds as a source of primary inoculum of the target spot is still unknown. Due to this, transmission efficiency from seed to seedling should be demonstrated and quantified.

The objectives of this study were to determine the incidence of $C$. cassiicola in soybean seeds produced in different Brazilian locations and evaluate the effects of this seed-borne pathogen concerning to physiological (seed germination, seedling emergence, and initial development of soybean seedlings) and epidemiological parameters (transmission of $C$. cassiicola by seeds to aboveground parts of soybean seedlings).

To determine the incidence of $C$. cassiicola in soybean seeds, 639 seed samples from different cultivars and produced in different Brazilian locations (Goiás, Mato Grosso, Mato Grosso do Sul, Paraná, Santa Catarina e São Paulo States) were analyzed, using the blotter test method. This work was carried out in TAGRO - Tecnologia Agropecuária Ltda, Londrina, PR. The Blotter test was performed according to international recommendations (NEERGAARD, 1979), with some modifications (GOULART, 1984). Four hundred soybean seeds per sample were placed into transparent plastic boxes -Gerbox ${ }^{\circledR}$ type - (20 seeds per gerbox), containing three sheets of qualitative filter paper previously moistened in diluted agar (10 $\mathrm{g}$ of agar $/ 1000 \mathrm{ml}$ of water) and incubated under 22 ${ }^{\circ} \mathrm{C}$ with alternating $12 \mathrm{~h}$ period of darkness and fluorescent white light, where they remained for seven days. After this period, the presence of $C$. cassiicola in the soybean seeds was recorded using a stereoscopic microscope. The pathogen identification was based on their morphological characteristics. The results were expressed in the percentage of contaminated seeds.

The effects of this seed-borne pathogen on physiological and epidemiological parameters were evaluated in experiments developed at Embrapa Western Agriculture, Dourados, MS, in October 2015, using soybean seeds inoculated with $C$. cassiicola (66\% of incidence). Seeds were inoculated according to the methodology developed by Tanaka, Menten, and Marianno (1989). Before inoculation, seeds asepsis was made by immersing them in sodium hypochlorite solution (1\%) for 3 min. Pure culture of C. cassiicola developed in PDA medium was used as inoculum. Plates were incubated in an incubation chamber under $22^{\circ} \mathrm{C}$ with alternating $12 \mathrm{~h}$ period of darkness and fluorescent white light, where they remained for 7 days. In each plate 50 seeds were placed in contact
GOULART, A. C. P.; UTIAMADA, C. M.

with the surface of the colonies, which was manually shaken for 30 seconds, allowing the adhesion of the inoculum to the surface of the seeds. The plates containing the inoculated seeds remained for 48 hours under laboratory conditions and then the seeds were air-dried for 24 hours on absorbent paper.

The seed germination was performed with one subsample of 50 seeds per replication, in a total of 200 seeds per treatment. The seeds were distributed on two sheets of Germitest ${ }^{\circledR}$ type paper rolls, moistened with distilled water in the proportion of 2.5 times the substrate dry mass. Next, the paper rolls were placed inside the germinator at $25{ }^{\circ} \mathrm{C}$ for 8 days. After that period, the normal seedlings were counted, and the results were expressed in percentage of normal and abnormal seedlings (BRASIL, 2009).

The physiological and epidemiological parameters were evaluated using the "growing on test" in experiments carried out in greenhouse conditions.

Seeds were sown in plastic trays $(56 \times 35 \times 10 \mathrm{~cm})$, containing sand previously sterilized. Two hundred seeds for each treatment were planted by placing them in equidistant $3-\mathrm{cm}-$ deep wells. The moisture was maintained through irrigation, according to the needs of the seed. The final evaluation was done 15 days after sowing computing the percentage of emerged normal seedlings, height and fresh weight of shoot, and root of soybean seedlings.

The occurrence of lesioned seedlings by the pathogen at 15 days after sowing was evaluated. These injured seedlings were collected and taken to the laboratory for analysis. Fragments of cotyledons and hypocotyl/root from these seedlings were washed and disinfested with $70 \%$ alcohol and $2 \%$ sodium hypochlorite, and then dried on sterile filter paper. After that, the fragments were incubated in humid chamber under $22^{\circ} \mathrm{C}$ with alternating $12 \mathrm{~h}$ period of darkness and fluorescent white light. Five days after incubation, the fragments were evaluated under stereoscopic microscope and fungal colonies were observed. The data obtained in this evaluation were used to calculate the transmission and rate of transmission of pathogen from the seeds to aboveground parts of soybean seedlings.

The data were submitted to variance analysis and the Student's t test was used to compare the means of the treatments.

The results about the occurrence of $C$. cassiicola in soybean seeds are shown in Table 1.

After the incubation period in the seed health test, it was observed, on the seeds, colonies 
Corynespora cassiicola...

ranging in color from gray to dark gray, with the presence of dense aerial mycelium (Figure 1A; 1B), conidiophores and conidia (Figure 1C), typical of $C$. cassiicola, which was confirmed on the basis of their morphological characteristics, according to Barnett; Hunter (1972).

In 2008 , an analysis of the sanitary quality of a seed sample from a commercial soybean crop, cultivar, FT Jaciara, susceptible to the target spot, from Campo Novo do Parecis, MT, revealed 27.0\% of $C$. cassiicola incidence. This result, although rare, suggests the possibility of the occurrence of this pathogen in the seeds at high levels, corroborating with those achieved subsequently by Camargo et al. (2013).

In the 639 analyzed samples, $C$. cassiicola was detected in $11.3 \%$ of them (frequency). The pathogen was recorded in every year the work was done, especially in 2011 , with $23.8 \%$ of the samples showing the pathogen, when compared to the results obtained in the other years. It should be emphasized that this large number of positive seed samples with C. cassiicola in that year, did not reflect in high incidence of the pathogen in seeds (average incidence $=0.38 \%$ and maximum incidence $=$ $2.25 \%$ ). In general, the average incidence of this pathogen in the seeds was $0.91 \%$, with the highest incidence $(8.5 \%)$ being observed in the seeds produced in 2015. The data obtained in the present study also corroborate with other researches that demonstrated the low levels of this pathogen in soybean seeds (ROIM et al, 1999).

From the year 2013 onwards, there was a trend in the increase of the occurrence of this pathogen in seeds, in terms of frequency and incidence, according to data presented in Figure 2. Considering that the incidence of this pathogen in the seeds is unusual, these results suggest that the presence of this pathogen in the seeds, to a greater or lesser incidence, can probably be attributed to the increase in incidence and severity of the target spot in soybean crops. According to Godoy (2015) reports, emerging target spot epidemics can be explained by either or both the lower sensitivity/resistance of the fungus to the fungicides most commonly used in soybean crops and introduction of more susceptible host genotypes.

Detection of phytopathogens in seeds has become increasingly important especially because of the relevance of this measure as part of plant health management (SOUSA; SIQUEIRA; MACHADO, 2016; SAJEESH et al.; 2014).

The seed health testing (blotter test) used in this research for the detection of $C$. cassiicola in soybean seeds was adequate for this purpose.
GOULART, A. C. P.; UTIAMADA, C. M.

The results regarding the relation of this seed-borne pathogen with physiological and epidemiological parameters, using inoculated seeds with $C$. cassiicola ( $66.0 \%$ de incidence), are shown in Table 2.

The transmission of $C$. cassiicola from the seeds to above-ground parts of soybean seedlings was demonstrated, by pathogen establishment on the cotyledon, shortly after the emergence, showing circular lesions with concentric rings, reddish-brown in the center and surrounded by a yellowish green halo, as a typical symptoms of target spot (Figura 1D). According to Lamotte et al., (2007), this yellowish color surrounding the lesions is a consequence of the toxin cassiicolin action, produced by pathogen, which is released into the cells and kills the tissues adjacent to the site of infection.

Considering a seed sample with $66.0 \%$ of $C$. cassiicola incidence, the symptomatic transmission of this fungus, based on the cotyledon symptoms, was $42.2 \%$, corresponding to a transmission rate of 2.4:1 (Table 2). It is known that the transmission process of a particular pathogen varies according to its incidence on the seeds. It means that the higher pathogen incidence on the seeds, the higher percentage of transmission. Based on these results, it can be inferred that infected seeds with $C$. cassiicola can play an important epidemiological role as source of primary inoculum of the disease in the field.

Seed germination, seedling emergence and seedling initial development (height and fresh weight of shoot and root) were influenced by the presence of the pathogen in the seeds, with the lowest values being observed when the seeds were inoculated (Table 2). Seedlings originated from inoculated seeds showed reduction of initial development (lower height), compared to those from non-inoculated seeds, as can be seen in Figure 1E. Reddish-brown lesions, superficial and without constriction, were also observed on the roots and stem of the seedlings, due to the presence of this pathogen in seeds (Figure 1F). Infected tissues were collected and taken to the laboratory for analysis. After the incubation period, fungal colonies were observed. Based on morphological characteristics, the pathogen was identified as C. cassiicola (Figure $1 \mathrm{G})$.

This is the first report, in a quantified way, of the transmission of $C$. cassiicola from the seeds to above-ground parts of soybean seedlings. It is important to state here that these results were obtained with artificially inoculated seeds, since the natural incidences are very lower than that used in 
Corynespora cassiicola...

the experiment. The present research provides information for pathology and for production of soybean seeds, since, nowadays, there are no studies determining this transmission.
GOULART, A. C. P.; UTIAMADA, C. M.

Means followed by the same letter in the line do not differ from each other according to $t$ Student test at $5 \%$ probability.

Table 1. Occurrence of Corynespora cassiicola in soybean seeds, from 2009 to 2015.

\begin{tabular}{ccccc}
\hline Year & $\begin{array}{c}\text { Number of } \\
\text { seed samples } \\
\text { analyzed }\end{array}$ & $\begin{array}{c}\text { Frequency } \\
\text { (\% of seed samples } \\
\text { with the pathogen) }\end{array}$ & $\begin{array}{c}\text { Average incidence of } \\
\text { pathogen in seed } \\
(\%)\end{array}$ & $\begin{array}{c}\text { Maximum incidence of } \\
\text { pathogen in seed } \\
(\%)\end{array}$ \\
\hline 2009 & 59 & 5,1 & 0,62 & 1,00 \\
2010 & 144 & 13,2 & 0,30 & 1,75 \\
2011 & 42 & 23,8 & 0,38 & 2,25 \\
2012 & 130 & 6,2 & 0,28 & 0,75 \\
2013 & 159 & 5,7 & 1,18 & 6,50 \\
2014 & 55 & 9,1 & 1,40 & 5,50 \\
2015 & 50 & 16,0 & 2,19 & 8,50 \\
\hline
\end{tabular}

Table 2: Effects of the presence of Corynespora cassiicola (C.c.) in soybean seeds in relation to physiological and epidemiological parameters.

\begin{tabular}{|c|c|c|}
\hline Evaluations & $\begin{array}{l}\text { Inoculated seed: } 66 \% \text { of } \\
\text { C. cassiicola incidence }\end{array}$ & $\begin{array}{l}\text { Non inoculated } \\
\text { seed }\end{array}$ \\
\hline Seed germination (\%) & $92,0 \mathrm{~b}$ & $97,5 \mathrm{a}$ \\
\hline Seedling emergence $(\%)$ & $93,0 \mathrm{~b}$ & $98,0 \mathrm{a}$ \\
\hline Seedlings with lesioned cotyledon & 28 seedlings $=15 \%$ & - \\
\hline Seedlings with lesioned hypocotyl/root & 112 seedlings $=60 \%$ & - \\
\hline Fresh weight of shoot $(\mathrm{g})$ & $0,95 \mathrm{~b}$ & $1,86 \mathrm{a}$ \\
\hline Fresh weight of root (g) & $0,44 \mathrm{~b}$ & $0,61 \mathrm{a}$ \\
\hline Seedling height $(\mathrm{cm})$ & $13,8 \mathrm{~b}$ & $18,6 \mathrm{a}$ \\
\hline \multicolumn{3}{|c|}{$\begin{array}{c}\text { Transmission (\%)=seedlings with C.c. (lesioned cotyledon)/incidence of C.c. in seeds x } 100 \\
\qquad \mathrm{~T}=42,2 \%\end{array}$} \\
\hline
\end{tabular}
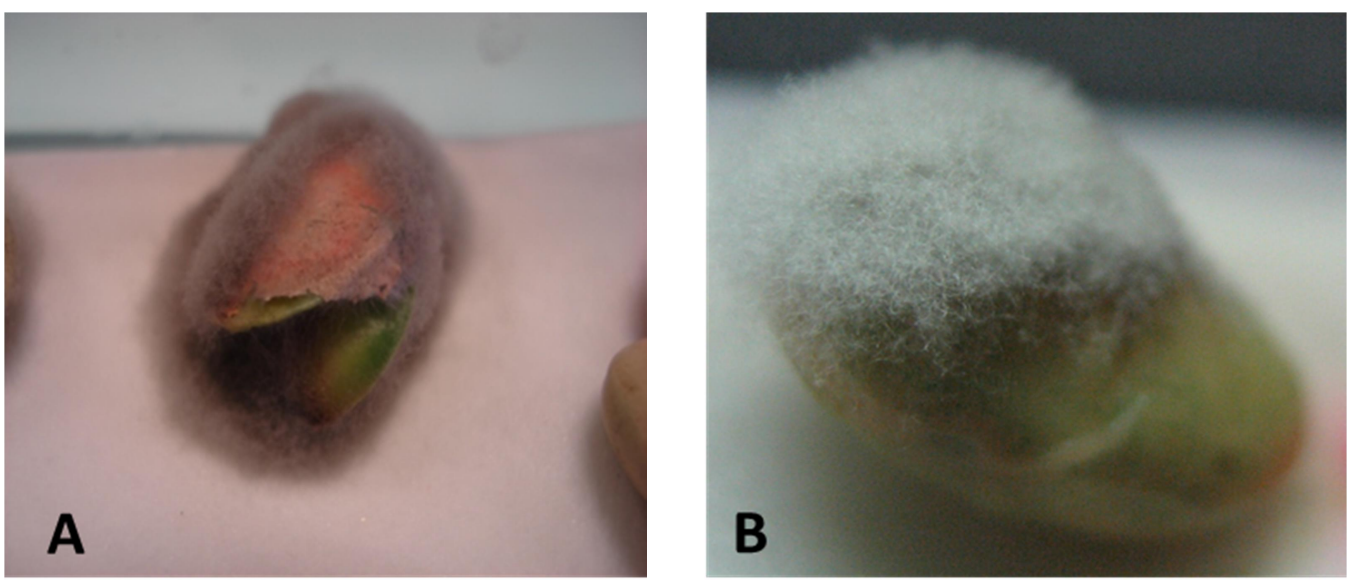

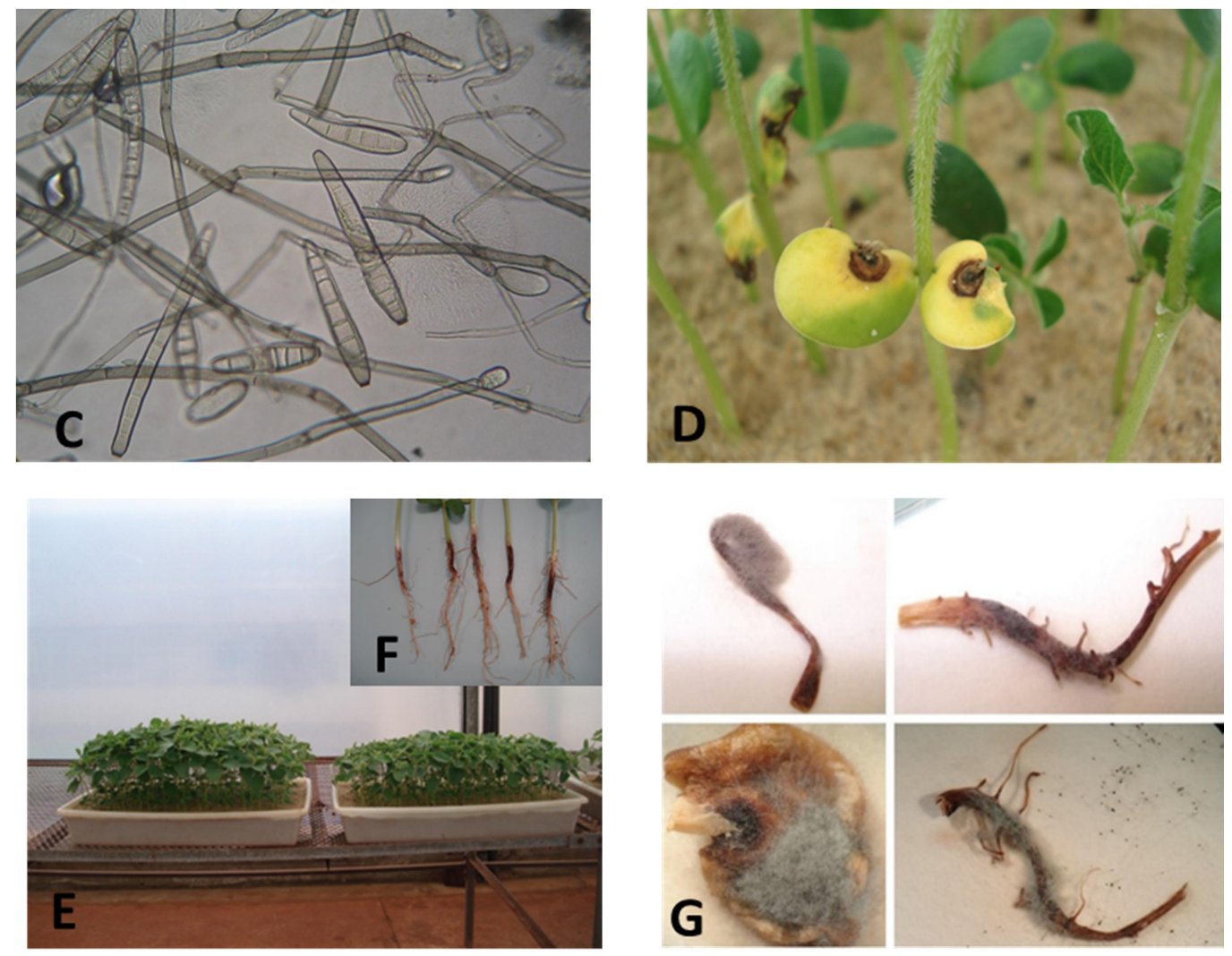

Figure 1. Corynespora cassiicola: typical growth on soybean seeds in the blotter test: A:inoculated seed and B: natural field infection; $\mathbf{C}$ : conidia and conidiophores of the pathogen; $\mathbf{D}$ : typical lesions in the soybean seedling cotyledons; E: comparison of seedling height from non-inoculated seeds (left) and inoculated seeds(right.); F: seedlings showing reddish-brown lesions in the roots and stem $\mathbf{G}$ : pathogen sporulation in lesioned tissues after incubation.

Photos: (A, D. E, F, G): Augusto C. P. Goulart (Embrapa/CPAO) and (B, C): Carlos M. Utiamada (TAGRO)

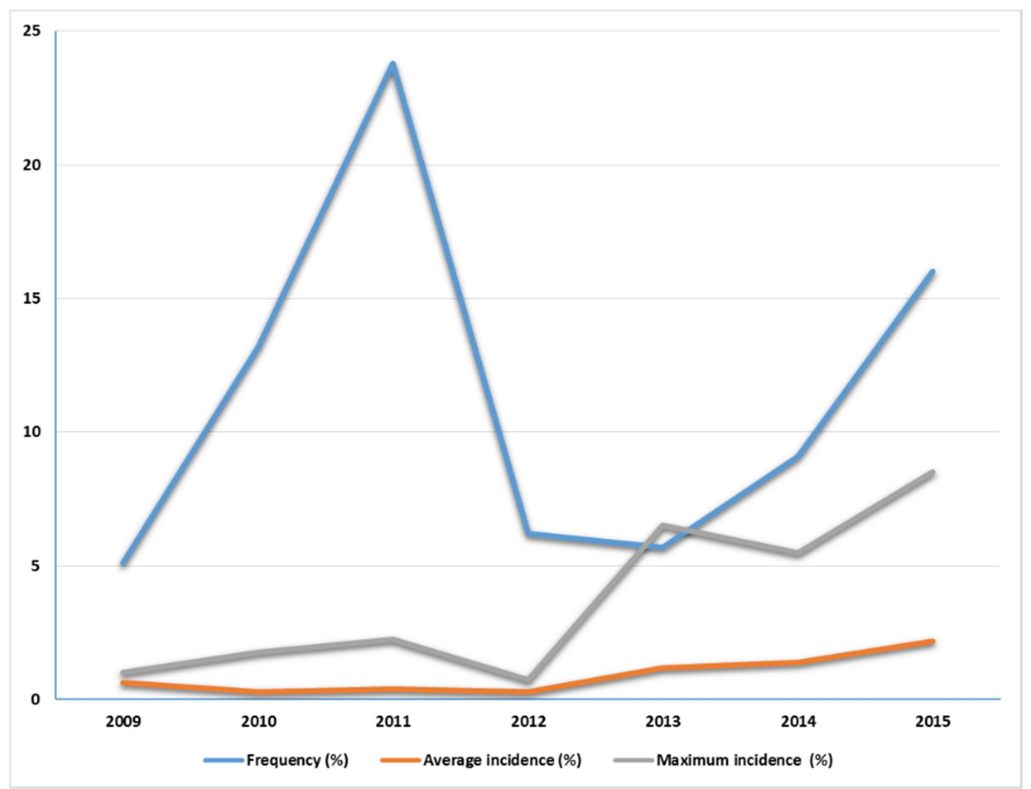

Figure 2. Corynespora cassiicola in soybean seeds: frequency (\% of seed samples with the pathogen) and average and maximum incidence (\%) of pathogen in seeds. 
RESUMO: O fungo Corynespora cassiicola, agente causal da mancha alvo da soja, tem sido considerado, do ponto de vista da patologia de sementes, um patógeno de importância limitada. Por esse motivo, pouca importância foi dada em relação ao papel das sementes na transmissão desse patógeno. Os objetivos desse trabalho foram determinar a incidência de $C$. cassiicola em sementes de soja bem como avaliar os efeitos da presença desse patógeno, inoculado nas sementes, com parâmetros fisiológicos e epidemiológicos. Os experimentos foram conduzidas na TAGRO e na Embrapa Agropecuária Oeste e constaram de testes de laboratório (blotter test e teste padrão de germinação) e de casa de vegetação (growing on test). $\mathrm{O}$ fungo $C$. cassiicola foi detectado em $11,3 \%$ das 639 amostras de sementes analisadas, com incidência média de $0,91 \% \mathrm{e}$ a máxima de $8,5 \%$. A transmissão de C. cassiicola, da semente para a parte aérea das plântulas de soja foi demonstrada, pelo estabelecimento do patógeno nos cotilédones, apresentando lesões circulares com anéis concêntricos, marrom-avermelhada no centro e com presença de halos amarelados, característicos da mancha alvo. Lesões radiculares e no colo das plântulas, de coloração marrom avermelhada, também foram observadas. Considerando a incidência de $C$. cassiicola na semente de $66,0 \%$, a transmissão sintomática do fungo baseada em sintomas no cotilédone, foi de 42,2\%, o que representou uma taxa de transmissão de 2,4:1. Esse é o primeiro relato, de forma quantificada, da transmissão de C. cassiicola das sementes para a parte aérea das plântulas de soja. Em comparação às sementes não inoculadas, a germinação das sementes, emergência e o desenvolvimento inicial das plântulas foram influenciados pela presença do patógeno nas sementes, com os menores valores sendo observados quando as sementes foram inoculadas.

PALAVRAS-CHAVE: Mancha alvo. Patologia de sementes.

\section{REFERENCES}

ALMEIDA, A. M .R.; MACHADO, C .C.; FERREIRA, L .P.; LEHMAN, P .S.; ANTONIO, H. Ocorrência de Corynespora cassiicola (Berk. \& Curt.) Wei no Estado de São Paulo. Fitopatologia Brasileira, Brasília, v. 1, n. 12, p. 111-112, 1976.

ALMEIDA, A. M. R.; FERREIRA, L. P.; YORINORI, J. T.; SILVA, J. F. V.; HENNING, A. A.; GODOY, C .V.; COSTAMILAN, L. M.; MEYER, M .C. Doenças da Soja. In: KIMATI, H.; AMORIM, L.; BERGAMIN FILHO, A.; CAMARGO, L. E. A.; REZENDE, J. A. M. (Eds.) Manual de fitopatologia: Doenças das plantas cultivadas. 4th ed. São Paulo: Agronômica Ceres, 2005.

BARNETT, H.L.; HUNTER, B.B. Illustrated genera of imperfect fungi. 3th ed. Minneapolis: Burgess, 1972, $241 \mathrm{p}$.

BRASIL. Ministério da Agricultura, Pecuária e Abastecimento. Regras para análise de sementes/Ministério da Agricultura, Pecuária e Abastecimento. Secretaria de Defesa Agropecuária. Brasília: Mapa/ACS, 2009, 399p. Available from: https://issuu.com/pesquisa-unificada/docs/2946 regras analise sementes

CAMARGO, M. P.; BONASSA; N.; MORAES, M. H. D.; MENTEN, J. O. M. Sobrevivência de Corynespora cassiicola em sementes de soja durante o armazenamento. Available from: http://www.summanet.com.br/summanet-site/congressos/2013/Resumos/Resumo36CPFito_125.pdf

GODOY, C. V. Target spot. In: HARTMAN, G. L.; RUPE, J. C.; SIKORA, E. J.; DOMIER, L. L.; DAVIS, J. A.; STEFFEY, K. L. (Eds.) Compendium of soybean diseases and pests. 5th ed. Saint Paul: APS Press, 2015.

GOULART, A. C. P. Avaliação do nível de ocorrência e efeitos de Phomopsis sp. e Sclerotinia sclerotiorum (Lib.) de Bary em sementes de soja (Glycine max (L.) Merrill). Dissertação (Mestrado em Fitotecnia) Escola Superior de Agricultura de Lavras, Lavras, 1984. 
LAMOTTE, F.; DUVIAU, M. P.; SANIER, C.; THAI, R.; PONCET, J.; BIEYSSE, D.; BRETON, F.; PUJADE-RENAUD, V. Purification and characterization of cassiicolin, the toxin produced by Corynespora cassiicola, causal agent of the leaf fall disease of rubber tree. Journal Chromatografy Biological analyst technology biomedical life science, Amsterdam, v. 849, n.1-2, p. 357-362, 2007.

https://doi.org/10.1016/j.jchromb.2006.10.051

NEERGAARD, P. Seed pathology. London: MacMillan, 1979. 839 p.

ROIM, F. L. B.; YORINORI, J. T.; UTIAMADA, C. M.; SATO, L. N. Transmissão de Corynespora cassiicola através da semente de soja.

Available from: https://ainfo.cnptia.embrapa.br/digital/bitstream/item/115829/1/Transmissao-de-Corynesporacassiicola-atraves-da-semente-de-soja.pdf. 1999.

SAJEESH, P. K.; RAO, M. S. L.; JAHAGIRDAR, S. Molecular detection, transmission and histopathological studies of seed-borne fungal infection of soybean (Glycine max (L.) Merrill). The Bioscan, Jharkhand, v. 9, n. 1, p. 247-251, 2014.

SINCLAIR, J.B.; BACKMAN, P.A. Compendium of Soybean Disease. 3rd ed. St. Paul: The American Phytopathological Society, 1989. 106p.

SOUSA, M. V.; SIQUEIRA, C. S. MACHADO, J. C. Conventional PCR for detection of Corynespora cassiicola in soybean seeds. Journal of Seed Science, Jardim Vitória Londrina, vol. 38, n. 2, p. 85-91, 2016. https://doi.org/10.1590/2317-1545v38n2152049

TANAKA, M. A. S., MENTEN, J. O. M.; MARIANNO, M. J. A. Inoculação artificial de sementes de algodão com Colletotrichum gossypii var. cephalosporioides e infecção das sementes em função do tempo de exposição ao patógeno. Summa Phytopathologica, Jaboticabal, n. 15, p. 232-23, 1989.

YORINORI, J.T. Levantamento e avaliação da situação de doenças da soja na safra 1987/88. In: Resultados de Pesquisa de soja, 1987/88. Londrina: Embrapa Soja, 1989. p.158. 